\title{
FACTORS INFLUENCING STUDENTS' READINESS FOR OUTSOURCING THEIR LOGISTICS
}

\author{
Vesna Rovšek, Bojan Beškovnik \\ Faculty of Maritime Studies and Transport, University of Ljubljana, Portorož, Slovenia \\ Submitted 5 March 2014; resubmitted 8 December 2014; accepted 16 February 2015; \\ first published online 15 June 2015
}

\begin{abstract}
The purpose of the present paper is to contribute to better knowledge of consumer logistics and consumer preferences. This aspect of logistics is to our mind rather unexplored, but seems to be very important for the development of logistics companies. The paper is confined to the logistics executed by the younger population. The main goal of the research was to identify the factors influencing students' readiness for outsourcing their logistics. Further, the survey aims at developing an instrument for measuring the scope and structure of the students' logistics and the share of their mobility which they would be ready to have executed by the suppliers of logistic services. Two segments were statistically analysed: social-demographic data and the diary of travel behaviour. Among twenty-two independent variables, the results highlighted 'length of journey', 'time necessary for the execution of logistics' for the purpose of: 'giving a ride to neighbours', 'shopping for consumer goods', 'change of residence' and 'entertainment'. Interestingly, it was ascertained that the more time the students travel by car, the more logistics they were prepared to outsource. Finally, the survey methodology applied might serve as the basis for further research into the market of logistic services as well as other aspects of consumers' preferences referring to their logistics. Based on this, new means of public transportation might be designed and offered by various localities.
\end{abstract}

Keywords: consumer logistics; students; travel behaviour; readiness for outsourcing; measuring instrument.

\section{Introduction}

Market saturation is a general characteristic of contemporary economies (Kotler, Keller 2011). Knowing consumer preferences in such conditions is of the utmost importance in order to adopt the right strategy for the supply of goods and services. This pertains to logistics companies, to suppliers of transportation and goods warehousing, transportation of people and goods, hirers of transportation means, etc. However, preferences of consumers regarding logistics services is an understudied area. Consequently, the suppliers supply what is available, instead of meeting the requirements of consumers.

Studies of consumer preferences have focused mostly on specific services and rarely on overall logistics (Bohte, Maat 2009). Here we begin to fill the void in studies of the readiness of consumers to have their outdoor logistics executed by suppliers of logistics services.

Our first research issue is the frequency of movement on the part of the subjects. A preliminary weekly measurement, carried out in spring of 2012 on the sample of 150 individuals, showed that weekly movements ranged from 0 to 48 , indicating quite a diverse phenomenon and demonstrates that a number of students are those individuals in society considered highly mobile with mostly 24 to 40 movements weekly.

The second research issue is the complexity of consumer mobility. For the same instances of travel, the student may consecutively use different transportation modes (e.g., a car one time, walksing the next). Even more complicated is the study of consumer logistics from the viewpoint of the purposes of individual movements. Unlike the supplier logistics - in which mobility has one, or, less often, two, purposes (e.g., collecting packaging while delivering goods) - the consumer's mobility has several purposes. These are at times carried out consecutively (e.g., stopping at a public office on the way to or from work), or simultaneously (for instance, going shopping on foot both for exercise and taking the opportunity to walk the dog), making measurement more difficult.

The third research issue is in regard to the consumers' preference for having others carry out their logistics. The preliminary weekly measurement showed that these 
consumers would like to have suppliers of logistic services execute only some of their travels or some of their purposes, managing others by themselves.

Given the complexity of consumer logistics research, it seems reasonable to begin the study with a small population. For this purpose the population of Slovenian students of the University of Ljubljana was selected (further: students). These students are very mobile, which makes data collecting rather difficult and with respect to the purposes of their mobility very diversified.

\section{Literature Review}

The theory of consumer logistics began to develop near the end of the 20th century. The means to improve the supply chain to meet the requirements of clients and enhance channel efficiency has long been an interest of scientists (Anderson, Narus 1990; Gupta, Loulou 1998; Christopher 2005; Savaskan, Van Wassenhove 2006). Alterations that increase efficiency, improve services, or both, do not necessarily lead to a reduction in opportunity costs, improve the chances of retaining clients and/ or limit the costs of transforming the channel (Christiaanse, Zimmerman 1999). Yet marketing literature generally deals with the changes in logistics activity in the direction through the channel towards clients, or the growing shift of service from the supplier to the selfservice (Rouquet et al. 2011). Thus, much of the marketing channels research excludes the role of the consumer in exercising logistics functions (Gehrt, O’Brien 2003). This gap is beginning to be filled by the theory of consumer logistics, which focuses on the exercise of logistics functions on the part of the consumer (Painter, Granzin 1996). Bowersox (1974) originally made a list of activities comprising the field of business logistics. The founders of consumer logistics theory, Granzin and Bahn (1989), applied his framework in the context of consumerism. Activities included in the theory are logistics exercised by the consumer alone within the household as well as between the consumer and the merchant (Granzin, Bahn 1989; Higuchi, Sakano 2003; Gehrt, Rajan 2007; Gehrt et al. 2007; Teller et al. 2008; Garver et al. 2012). The majority of studies in the field of logistics science focus above all on 'industrial' logistics; i.e., essentially the process of distribution. Thus, the consumer's role in the logistics system (e.g., a housewife who participates in the goods flow while carrying foodstuff from the market or storing it in the pantry for the future) had long been almost entirely neglected. Nevertheless, the theory has now been applied, e.g., to shopping (Granzin 1990; Painter, Granzin 1996), internet banking (Higuchi, Sakano 2003; Gehrt, O'Brien 2003) and specific services of railway passenger traffic (Gehrt et al. 2007). In the traditional sense, consumer logistics deals with the functions which include determining location, transportation, information transfer, handling/warehousing and stocks (Waite, Harrison 2002).

The theory of planned behaviour (Ajzen 1991) is probably the most frequently applied social-psycholog- ical theory about the factors that may affect the behavioural intentions of people making travel decision (Bamberg et al. 2003; Gardner, Abraham 2008; Murtagh et al. 2012; Cools, Creemers 2013). In combination with the latter, the theory of consumer logistics is appropriate for arriving at a better understanding of the process of consumers making decisions about the purchase or the choice of logistics services (Granzin, Bahn 1989; Bowersox et al. 2000; Reutterer, Kotzab 2000; Christopher 2005; Anderson et al. 2011; Garver et al. 2012). Many studies have been carried out with respect to the travel behaviour of various segments of the population (Johansson et al. 2006; Rajé 2007; Lois, López-Sáez 2009; Van Exel, Rietveld 2009), regarding various purposes of movement, such as shopping for food, transportation of children to and from school, as part of exercising leisure time (Anable 2005), and for work (Shuttleworth, Gould 2010; Silver 2011). Some scientific papers deal with the use of various modes of transportation (FiorenzoCatalano et al. 2003; Manaugh 2009; Bonham, Koth 2010; Gatersleben, Haddad 2010; Hagman 2010; Handy et al. 2010) and the role of many factors (e.g. socio-demographic) that influence the choice and frequency of travelling (Boarnet, Sarmiento 1998; Best, Lanzendorf 2005; Bergstad et al. 2011).

The majority of studies of the travel behaviour of youth are focused on analysing their choice of the transportation mode for a certain purpose - e.g., going to school (Evenson et al. 2003; Hume et al. 2009; Irawan, Sumi 2011) - or relating to various factors such as gender, age, parents' income, etc. (Vovsha, Petersen 2005; McMillan 2007; Irawan, Sumi, 2011). A few authors focus their research on the student population (Kerr et al. 2010; Irawan, Sumi 2011; Kamruzzaman et al. 2011; Khattak et al. 2011; Wang et al. 2012) as this segment involves a variety of daily as well as yearly instances of movement using various transportation modes (Jacobucci 2002), so from the logistics viewpoint students may be treated as a potential segment that would, considering eventual fares allowances, use more permanent modes of transportation (Jacobucci 2002); promote active transportation facilitating better physical health (Irawan, Sumi 2011); and influence tourism development planning (Xu et al. 2009), etc. The student population is worth consideration with a view toward future transportation planning as well as development and formation of logistics services meeting the requirements of the specific consumer.

\section{Purpose and Methodology}

The purpose of the research was to define the role of the examined factors in the readiness of students for outsourcing their outdoor logistics. Such information has a useful value, be it for future transportation planning or for the suppliers of logistics services in focusing their promotion activities, in creating new logistics services, designing specific marketing research for the selected types of logistic services, and so on. 
Specific objectives were to identify the role of the following factors in the readiness for outsourcing:

- gender;

- parents' education;

- time taken for a definite purpose of movement;

- time taken with a specific mode of movement/ transportation.

\subsection{Research Instrument}

For this research a unique four page anonymous questionnaire was developed. It was divided into three sections (I - Instructions for completing, II - Social-demographic data, III - Diary of the students' logistics).

Many particular logistics dimensions were measured; however, in this paper are presented only the summary data completed on the basis of weekly movements of individual students. We inquire into the readiness of students for outsourcing of their outdoor logistics (presented in detail in Section 3.3).

In order to measure the students' logistics and their readiness for outsourcing the questionnaire contained 19 questions. The variables treated in this paper are presented in detail in the next section.

\subsection{Data Collection and Analysis}

The research was carried out during the academic year 2012-2013. Recording of the students' travel behaviour was carried out during an ordinary academic week with no holidays. It began on Monday and finished on Sunday evening.

The questionnaire with instructions was handed out to 240 students. There were $186(77.5 \%)$ valid responses handed in.

Statistical analysis of the model set was performed with MATLAB ${ }^{\circledR}$ Statistics Toolbox. First, the variables were edited, coded and explored. Frequency tables, basic statistics, data distribution and correlation coefficients among indicators as a measure for data validity were used. In the last stage we identified the role of different factors in the readiness for outsourcing using the bivariate statistical analysis.

Upon reviewing the frequency distribution of data it turned out that the majority of students during the week of applying the measurement instrument did not encounter some of the purposes we supposed. Table 1 shows that too low a percentage of answers was given to the question of repair/servicing of goods (5\%), and also to 'drive with no destination' (8\%), 'other' (9\%), 'visit doctor/therapist' (11\%), 'other personal services' (11\%), 'trip' (11\%), 'errands at the offices' (14\%), 'hobby' (14\%) and 'public or social event' (15\%). Additional explanation is necessary for 'recreation' and 'walking the dog'. They were recorded by $76 \%$ and $21 \%$ students, respectively; however, the answers of readiness for outsourcing their logistics are concentrated on one value. Therefore, none of these purposes are included in the final analysis.

Table 1. Distribution of answers and readiness of students for outsourcing their logistics by purposes

\begin{tabular}{|c|c|c|c|c|c|c|c|c|c|}
\hline \multicolumn{4}{|c|}{ Frequency of answers } & \multicolumn{4}{|c|}{$\begin{array}{l}\text { Distribution of readiness for } \\
\text { outsourcing logistics }\end{array}$} & \multicolumn{2}{|c|}{ Purposes of logistics } \\
\hline \multicolumn{2}{|c|}{ Valid } & \multicolumn{2}{|c|}{ Missing } & \multicolumn{2}{|c|}{ Yes } & \multicolumn{2}{|c|}{ No } & \multirow{2}{*}{$\begin{array}{l}\text { Finally analysed } \\
\text { change of residence }\end{array}$} & \multirow[t]{2}{*}{ Finally not analysed } \\
\hline 96 & $52 \%$ & 90 & $48 \%$ & 71 & $74 \%$ & 25 & $26 \%$ & & \\
\hline 46 & $25 \%$ & 140 & $75 \%$ & 27 & $59 \%$ & 19 & $41 \%$ & work & \\
\hline 186 & $100 \%$ & 0 & $0 \%$ & 132 & $71 \%$ & 54 & $29 \%$ & school/education & \\
\hline 73 & $39 \%$ & 113 & $61 \%$ & 38 & $52 \%$ & 35 & $48 \%$ & giving a ride to neighbours & \\
\hline 42 & $23 \%$ & 144 & $77 \%$ & 18 & $43 \%$ & 24 & $57 \%$ & shopping for durable goods & \\
\hline 146 & $78 \%$ & 40 & $22 \%$ & 76 & $52 \%$ & 70 & $48 \%$ & shopping for consumer goods & \\
\hline 10 & $5 \%$ & 176 & $95 \%$ & & & & & & repair/servicing of goods \\
\hline 26 & $14 \%$ & 160 & $86 \%$ & & & & & & errands at the offices \\
\hline 20 & $11 \%$ & 166 & $89 \%$ & & & & & & doctor/therapist \\
\hline 20 & $11 \%$ & 166 & $89 \%$ & & & & & & other personal services \\
\hline 49 & $26 \%$ & 137 & $74 \%$ & 19 & $39 \%$ & 30 & $61 \%$ & work around the home & \\
\hline 158 & $85 \%$ & 285 & $15 \%$ & 74 & $47 \%$ & 84 & $53 \%$ & bar/restaurant & \\
\hline 86 & $46 \%$ & 100 & $54 \%$ & 32 & $37 \%$ & 54 & $63 \%$ & entertainment & \\
\hline 27 & $15 \%$ & 159 & $85 \%$ & & & & & & public or social event \\
\hline 26 & $14 \%$ & 160 & $86 \%$ & & & & & & hobby \\
\hline 131 & $70 \%$ & 55 & $30 \%$ & 48 & $37 \%$ & 83 & $63 \%$ & visit & \\
\hline 141 & $76 \%$ & 45 & $24 \%$ & 20 & $14 \%$ & 121 & $86 \%$ & & recreation \\
\hline 39 & $21 \%$ & 147 & $79 \%$ & 5 & $13 \%$ & 34 & $87 \%$ & & walking the dog \\
\hline 20 & $11 \%$ & 166 & $89 \%$ & & & & & & trip \\
\hline 14 & $8 \%$ & 172 & $92 \%$ & & & & & & drive with no destination \\
\hline 17 & $9 \%$ & 169 & $91 \%$ & & & & & & other \\
\hline
\end{tabular}


A low percentage of answers was also given regarding the use of bicycle, motorcycle and other modes of travel, which is shown in Table 2.

The final analysis deals also with two derived variables; e.g., 'the number of journeys in the studied week' and 'the number of journeys with more than one purpose'. It should also be noted that the question of how many minutes they would be ready to outsource referred only to those journeys that were not executed by public transportation. Therefore, the use of public transportation was also used only in the description of the population.

A description of variables included in the final analysis is shown in Table 3.

Table 2. Distribution of answers and the use of individual modes of travel

\begin{tabular}{|c|c|c|c|c|c|c|c|c|c|}
\hline \multicolumn{4}{|c|}{ Frequency of answers } & \multicolumn{4}{|c|}{ Distribution of modes of travel } & \multicolumn{2}{|c|}{ Modes of travel } \\
\hline \multicolumn{2}{|c|}{ Valid } & \multicolumn{2}{|c|}{ Missing } & \multicolumn{2}{|c|}{ Yes } & \multicolumn{2}{|c|}{ No } & \multirow{2}{*}{$\begin{array}{l}\text { Finally analysed } \\
\text { on foot }\end{array}$} & \multirow[t]{2}{*}{ Finally not analysed } \\
\hline 186 & $100 \%$ & 0 & $0 \%$ & 186 & $100 \%$ & 0 & $0 \%$ & & \\
\hline 186 & $100 \%$ & 0 & $0 \%$ & 33 & $18 \%$ & 153 & $82 \%$ & & bicycle \\
\hline 186 & $100 \%$ & 0 & $0 \%$ & 18 & $10 \%$ & 168 & $90 \%$ & & motorcycle \\
\hline 186 & $100 \%$ & 0 & $0 \%$ & 186 & $100 \%$ & 0 & $0 \%$ & car-driver & \\
\hline 186 & $100 \%$ & 0 & $0 \%$ & 151 & $81 \%$ & 35 & $19 \%$ & car-companion & \\
\hline 186 & $100 \%$ & 0 & $0 \%$ & 73 & $39 \%$ & 113 & $61 \%$ & & public transportation \\
\hline 186 & $100 \%$ & 0 & $0 \%$ & 16 & $9 \%$ & 170 & $91 \%$ & & other \\
\hline
\end{tabular}

Table 3. Description of the variables included in the final analysis

\begin{tabular}{|c|c|c|}
\hline Label & Description & Independent variables \\
\hline \multirow[t]{2}{*}{$\begin{array}{l}1 \\
2\end{array}$} & $\begin{array}{l}\text { male } \\
\text { female }\end{array}$ & gender \\
\hline & years & age \\
\hline $\begin{array}{l}1 \\
2 \\
3 \\
4 \\
5\end{array}$ & $\begin{array}{l}\text { elementary school (incomplete, complete) } \\
\text { vocational school } \\
\text { high school } \\
\text { community college ( } 2 \text { years) } \\
\text { higher school and over }\end{array}$ & father's education \\
\hline $\begin{array}{l}1 \\
2 \\
3 \\
4 \\
5\end{array}$ & $\begin{array}{l}\text { elementary school (incomplete, complete) } \\
\text { vocational school } \\
\text { high school } \\
\text { community college ( } 2 \text { years) } \\
\text { higher school and over }\end{array}$ & mother's education \\
\hline \multirow[t]{7}{*}{$\begin{array}{l}1 \\
2 \\
3 \\
\end{array}$} & $\begin{array}{l}\text { town } \\
\text { town outskirts } \\
\text { village }\end{array}$ & type of permanent residence \\
\hline & minutes & duration of logistics \\
\hline & kilometres & length of journey \\
\hline & sum & number of journeys \\
\hline & sum & number of journeys with more purposes \\
\hline & $\begin{array}{l}\text { change of residence in minutes } \\
\text { work in minutes } \\
\text { school/education in minutes } \\
\text { giving a ride to neighbours in minutes } \\
\text { shopping for durable goods in minutes } \\
\text { shopping for consumer goods in minutes } \\
\text { work around the home in minutes } \\
\text { bar/restaurant in minutes } \\
\text { entertainment in minutes } \\
\text { visit in minutes }\end{array}$ & purposes of logistics \\
\hline & $\begin{array}{l}\text { on foot in minutes } \\
\text { car-driver in minutes } \\
\text { car-companion in minutes }\end{array}$ & mode of travel \\
\hline \multirow[t]{2}{*}{ Label } & Description & Target variable \\
\hline & minutes & $\begin{array}{l}\text { total time of logistics not executed by public transportation and you } \\
\text { would be ready to have it executed by suppliers of logistics service }\end{array}$ \\
\hline
\end{tabular}

Note: ${ }^{*}$ Students answered the question with the assumption that the price and quality of service are favourable. Students answered considering the total time, not specifically for each mode of travel and purpose. 


\section{Results}

\subsection{Demographic Data}

A valid measuring instrument was handed in by 186 students. Most of the students included in the research were males $(75 \%)$. The average age was 21 years (ranging from 18 to 29). The greatest share were 20 (29\%) and 19 (24\%), and the smallest share were 18 and 25 or more (together 3\%).

The largest share of fathers of the interviewed students had 11 years of education (35\%), followed by fathers with 12 years of education (25\%) and fathers with 16 or more years of education (21\%). Most mothers of the interviewed students completed 12 years of education $(37 \%)$, followed by mothers with 16 or more years of education $(22 \%)$ and 11 years of education (19\%).

The data showed students of all Slovenian regions participated in the research. $77 \%$ of students answered that their place of permanent residence was a village

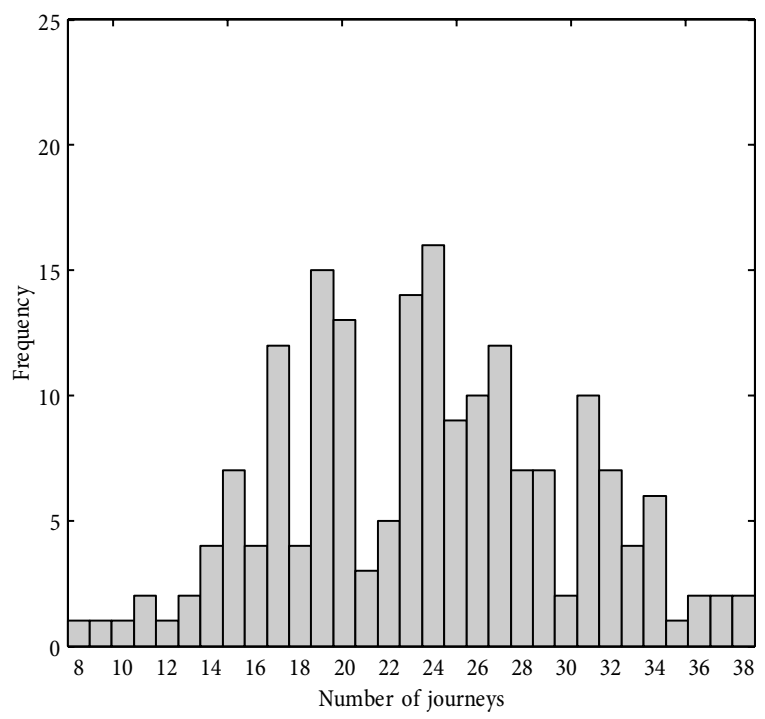

Fig. 1. Frequency distribution of students by the number of journeys
(39\%) or a town $(38 \%)$. Regarding temporary residence, the results show that 71 students had no such residence, leading to the conclusion that their everyday way to school was made from their permanent residence.

The interviewed population was almost without health or physical problems that might have impeded their mobility. Temporary physical problems were expressed by 9 students; however, nobody mentioned permanent problems, such as physical disability, chronic illness, etc.

\subsection{Characteristics of Students' Logistics}

The students altogether spent 162790 minutes or 875 minutes on average for the execution of their logistics. The majority of their logistics during the week lasted between 375 and 1125 minutes.

The students altogether covered 72295 kilometres, or 389 kilometres on average. The results show that individually there was a significant difference in the kilometres travelled, from 9 to 1344 kilometres. The length of the journey made by students mainly ranged from 100 to 600 kilometres.

They made 4407 journeys altogether, 795 of which had more than one purpose. On average they made 24 journeys, 4 of which were organized so as to accomplish several purposes. Fig. 1 shows that the number of journeys ranged from 8 to 38 . Most frequent was 24 journeys. The number of journeys with several purposes also varied significantly, but, as expected, was somewhat lower. The majority of students (154 or $83 \%$ ) made at least one journey, some of them (15 or $8 \%$ ) also made more than 10 journeys that had several purposes.

The students included in the research travelled for various purposes. As stated in the above paragraph, the purposes of their mobility were recorded both separately and together. The latter depended above all on the fact when they took decision for a certain purpose and when it ended as well as which was the main purpose. Fig. 2 shows that most of the time spent on journeys was for the following purposes: 'school/education', 'rec-

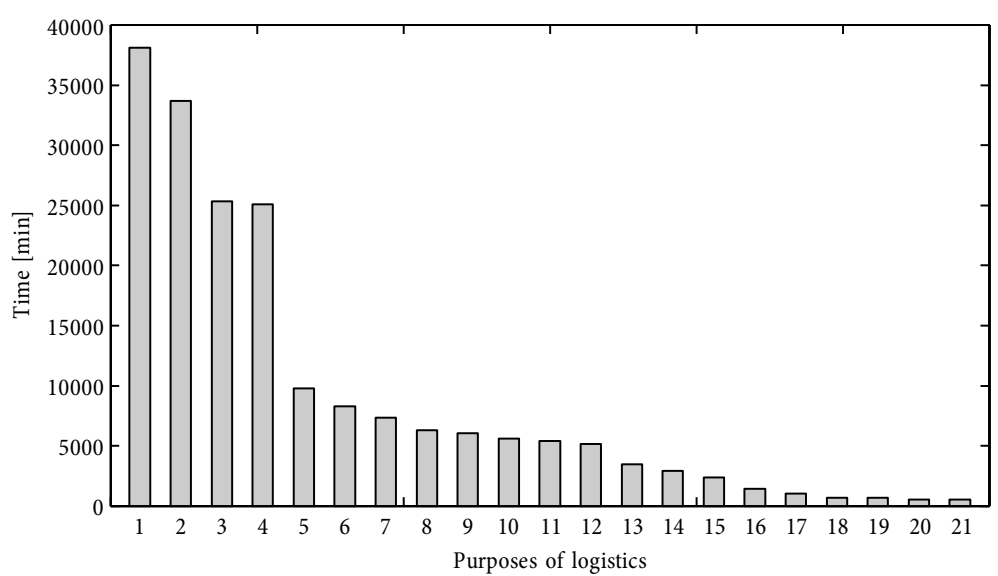

Fig. 2. Duration of logistics with respect to individual purposes: 1 - school/education; 2 - recreation; 3 - bar/restaurant; 4 - change of residence; 5 - visit; 6 - shopping for consumer goods; 7 - work around the home; 8 - walking the dog; 9 - giving a ride to neighbours; 10 - trip; 11 - entertainment; 12 - work; 13 - hobby; 14 - public or social event; 15 - shopping for durable goods; 16 - other; 17 - drive with no destination; 18 - errands at the offices; 19 - visit doctor/therapist; 20 - repair/servicing of goods; 21 - other personal services 
reation', 'bar/restaurant' and 'change of residence'. Following were: 'visit', 'shopping for consumer goods' and 'work around the home', etc. By frequency distribution it was determined that the purpose 'school/education' was common to all students. For the majority there were also other common purposes: 'bar/restaurant' (85\%), 'shopping for consumer goods' (78.5\%), 'recreation' (76\%) and 'visit' (70\%). About half of the students went on a journey for the purpose of 'changing residence' (52\%). Thus, the conclusion can be made that of the $62 \%$ of students with a temporary residence $10 \%$ did not return to their permanent residence. 'Entertainment' was recorded as a reason for travel by $46 \%$ of students.

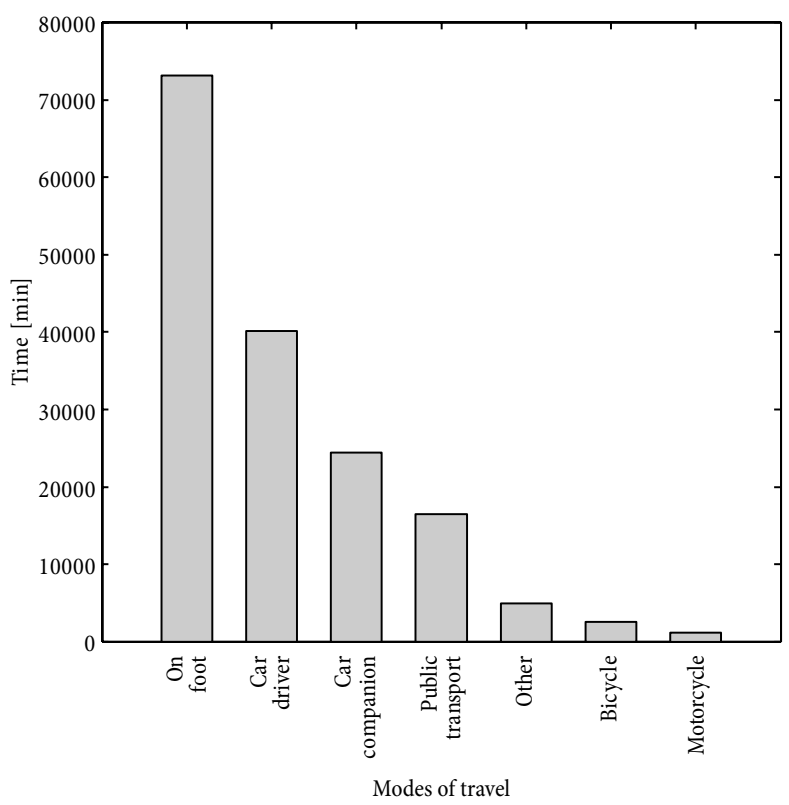

Fig. 3. Modes of travel used

The analysis of the modes of travel showed that $45 \%$ of the journeys were made on foot, $25 \%$ as the drivers of passenger cars and $15 \%$ as car-companions. Fewer $(10 \%)$ used public transportation. Bicycle, motorcycle and other means of mobility represent only $5 \%$ of the overall journeys (Fig. 3). Most of the students, 97\%, made their journeys on foot, $82 \%$ as car-drivers and $81 \%$ as car-companions. Public transportation was used by $39 \%$ of students. The least, only $36 \%$, used a bicycle, motorcycle and other modes.

\subsection{Readiness to Outsource Logistics}

The diary was designed to enable students to answer the question for each journey: how many minutes would they be ready to have logistics, non-public transportation, executed by suppliers of logistics services? The analysis showed that the students were on average ready to have 165 minutes executed by suppliers. The sum of all minutes per student ranged from 0 to 705 . The results also show that most participants $(89 \%)$ were ready to have some degree of logistics executed by others. This totals 30644 minutes - i.e., 2.75 hours per student on average. For the supplier of logistics services it means 4378 minutes daily of potential demand.
The research further determined the role of various factors in the decision of students to outsource their logistics.

In the analysis of gender the t-test was used for the independent samples. The statistic calculation shows that men were ready to have more time executed by suppliers than women, 175 and 134 minutes, respectively, on average. However, on the basis of Levene's Test for Equality of Variances $(P(F)=0.085 \rightarrow P>0.05)$ it is not possible to conclude that women are less ready to have logistics executed by suppliers than men. Due to the high level of characteristics of t-test $(P=0.085 \rightarrow P>0.05)$ the null hypothesis was confirmed; i.e., that the means of populations statistically do not differ significantly.

One-Way analysis of the variance (ANOVA) was applied with respect to the parents' education. The test of homogeneity of variances calculated that the variances between groups statistically do not differ significantly $(P>0.05)$, which confirms that the ANOVA is valid. It was determined that the means between subgroups of the education of fathers statistically do not differ significantly $(P(F)=0.427 \rightarrow P>0.05)$. The same applies with respect to the education of mothers $(P(F)=$ $0.336 \rightarrow P>0.05)$, which was in both cases also confirmed by a post-hoc test. In this case the alternative hypothesis was also rejected and the null hypothesis accepted: that the means of individual groups were not statistically different.

Numerical variables were analysed using Pearson's correlation coefficient. The results are shown in Table 4, where the variables the length of journey and the readiness to have outdoor logistics executed by suppliers of logistics services have a positive linear correlation. Pearson's correlation coefficient is $r=0.256$ and is statistically significant at the 0.01 level. It also applies to the time taken for the purposes of 'giving a ride to neighbours' and 'shopping for consumer goods'. For both variables it can be claimed with $1 \%$ risk that they have a weak positive linear correlation with the target variable; the Pearson's correlation coefficient is $r=0.236$ and $r=0.204$, respectively. With a $5 \%$ risk we may claim that the positive linear correlation between the time spent for the purposes 'change of residence' or 'entertainment' and the target variable is statistically significant, though negligible. The calculated Pearson's correlation coefficient is $r=0.146$ and $r=0.154$, respectively. The analysis of modes of travel showed a weak positive linear correlation between the variables 'car-driver' and 'readiness for outsourcing. The Pearson's correlation coefficient is $r=0.257$ and is statistically significant at the 0.01 level. The Pearson's correlation coefficient between the variable 'car-companion' and the target variable is $r=0.174$ and indicates a positive linear correlation. The value of correlation is negligible but statistically significant at the 0.05 level. Regarding other variables it would be risky to claim that they influence the readiness for outsourcing.

In order to measure the correlation between the target variable and the variables 'work', 'shopping for durable goods', 'work around the home' (whose numerical values were due to non-normal distribution transformed 
Table 4. Correlation between individual independent variables and the target variable

\begin{tabular}{|c|c|c|c|c|}
\hline \multirow[b]{2}{*}{ Independent variables } & \multicolumn{4}{|c|}{ Readiness for outsourcing logistics } \\
\hline & Pearson correlation & Spearman correlation & Sig. (2-tailed) & $\mathrm{N}$ \\
\hline Age & -0.015 & & 0.834 & 186 \\
\hline Type of permanent residence & & -0.013 & 0.865 & 186 \\
\hline Duration of logistics & 0.143 & & 0.051 & 186 \\
\hline Length of journey & $0.256^{\star *}$ & & 0.000 & 186 \\
\hline Number of journeys & 0.113 & & 0.125 & 186 \\
\hline Number of journeys with more purposes & 0.054 & & 0.462 & 186 \\
\hline Time: change of residence & $0.146^{*}$ & & 0.047 & 186 \\
\hline Time: work & & -0.059 & 0.424 & 186 \\
\hline Time: school/education & -0.004 & & 0.958 & 186 \\
\hline Time: giving a ride to neighbours & $0.236^{* *}$ & & 0.001 & 186 \\
\hline Time: shopping for durable goods & & 0.049 & 0.508 & 186 \\
\hline Time: shopping for consumer goods & $0.204^{* *}$ & & 0.005 & 186 \\
\hline Time: work around the home & & 0.101 & 0.170 & 186 \\
\hline Time: bar/restaurant & 0.120 & & 0.102 & 186 \\
\hline Time: entertainment & $0.154^{*}$ & & 0.036 & 186 \\
\hline Time: visit & 0.065 & & 0.375 & 186 \\
\hline Time: on foot & 0.053 & & 0.471 & 186 \\
\hline Time: car-driver & $0.257^{\star *}$ & & 0.000 & 186 \\
\hline Time: car-companion & $0.174^{*}$ & & 0.018 & 186 \\
\hline
\end{tabular}

Notes: ${ }^{\star}$ correlation is significant at the 0.05 level (2-tailed); ${ }^{\star \star}$ correlation is significant at the 0.01 level (2-tailed).

into three classes) and 'permanent residence', the Spearman correlation is used. Table 4 shows that regarding these latter variables it would be risky to claim that they correlate with the target variable.

\section{Discussion}

The research is confined to the study of a particular segment of the population due to the complexity of such studies in general. For this purpose a measuring instrument was developed and used for the observation and measuring outdoor logistics activities of a particular group of people, university students.

The weekly diary method used signifies a scientific contribution, above all by recording various types of purposes that the student has for making individual journeys, by measuring the extent of their logistics and the share of logistics the individual is ready to have executed by others. The methodological contribution represents the study of factors influencing the readiness of students to outsource. Significantly, the measuring instrument may be applied to other segments of the population.

The research showed that during the time of fulfilment of the measuring instrument the respondents made 24 journeys on average, 4 of which were organized so as to achieve more than one end. Most of the time was used for journeys with the purposes 'school/ education', 'recreation,' 'bar/restaurant' and 'the change of residence'; $45 \%$ of their logistics was made 'on foot', $25 \%$ as 'car-drivers' and 15\% as 'car-companions'.
Students were ready to have around 511 hours executed by others. That means 73 hours daily of potential demand for the suppliers of logistics services.

With the bivariate analysis the role of the examined factors in the readiness of students for outsourcing were identified. With $1 \%$ risk we may claim that the variables 'length of journey' and time used for the execution of logistics to 'give a ride to neighbours' and 'shopping for consumer goods' have a positive linear correlation with the target variable. Also, between the variable 'cardriver' and the target variable a positive linear correlation is demonstrated that is statistically significant at the $1 \%$ level. However, with $5 \%$ risk it may be claimed that the positive linear correlation is statistically significant between the times spent in order to accomplish the purposes 'change of residence' and 'entertainment' and the target variable. The correlation coefficient between the variable 'car-companion' and the target variable also indicates a positive linear correlation that is statistically significant at the 5\% level. Regarding other variables it would be risky to claim that they correlate with the target variable.

Preliminary weekly measurement shows that the students are among those individuals who engage in a lot of activities and thus have a high need to be mobile. The results of this study should help logistics providers develop strategies to facilitate effective logistics support for university students and improve the efficiency and profitability of marketing activities. Moreover, the study may be a good basis for the execution of a more com- 
prehensive research model which would also include the preferences of other segments of consumers. This could be applied to individual municipalities. The information obtained could enable local authorities to more effectively organise logistic services, better matching transport systems to the needs of users.

\section{Conclusions}

1. The purpose of this study was to analyse the extent and structure of students' outdoor logistics and the share of their logistics that they are ready to outsource. A second but no less important goal was to identify the role of factors in the readiness for outsourcing outdoor logistics, which facilitates better understanding of students' preferences. The lack of research that would provide such findings establishes the applicability of the paper.

2. For the week measured the students were altogether ready to outsource 30644 minutes; i.e., around 3 hours per student on average. This amounts to a daily total of 4378 minutes of potential demand for the suppliers of logistics services.

3. With respect to the results of the bivariate analysis we may conclude that gender and parents' education have no influence on the readiness of students for outsourcing logistics. Further, the more time the students spent to execute their logistics to accomplish the purposes, such as 'giving a ride to neighbours', 'shopping for consumer goods', 'change of residence' and 'entertainment', the more time of their logistics they were ready to outsource. Moreover, the more time the students spent travelling by car, be it as a driver or companion, the more time of their logistics they were ready to outsource. Finally, the students whose overall weekly length of journey was longer were ready for outsourcing more time of their logistics than those whose journey was shorter.

4. The research is confined to the university student population; however the results may be a good basis for further research into the market of logistic services and the preferences of other segments of the consumers' logistics. With this, a wider model of outdoor logistics and mobility might be developed on a local or national level.

\section{Acknowledgements}

The research was partly co-financed by the European Union from the European social fund. Co-financing was implemented in the framework of the Operative program of development of human resources for the period 2007-2013. The authors would like to thank I. Ostan and E. Podovšovnik Axelsson for their advice in preparing the questionnaire.

\section{References}

Ajzen, I. 1991. The theory of planned behavior, Organizational Behavior and Human Decision Processes 50(2): 179-211. http://dx.doi.org/10.1016/0749-5978(91)90020-T

Anable, J. 2005. 'Complacent car addicts' or 'aspiring environmentalists'? Identifying travel behaviour segments using attitude theory, Transport Policy 12(1): 65-78. http://dx.doi.org/10.1016/j.tranpol.2004.11.004

Anderson, E. J.; Coltman, T.; Devinney, T. M.; Keating, B. 2011. What drives the choice of a third-party logistics provider?, Journal of Supply Chain Management 47(2): 97-115. http://dx.doi.org/10.1111/j.1745-493X.2011.03223.x

Anderson, J. C.; Narus, J. A. 1990. A model of distributor firm and manufacturer firm working partnerships, Journal of Marketing 54(1): 42-58. http://dx.doi.org/10.2307/1252172

Bamberg, S.; Ajzen, I.; Schmidt, P. 2003. Choice of travel mode in the theory of planned behavior: the roles of past behavior, habit, and reasoned action, Basic and Applied Social Psychology 25(3): 175-188.

http://dx.doi.org/10.1207/S15324834BASP2503_01

Bergstad, C. J.; Gamble, A.; Hagman, O.; Polk, M.; Gärling, T.; Olsson, L. E. 2011. Affective-symbolic and instrumentalindependence psychological motives mediating effects of socio-demographic variables on daily car use, Journal of Transport Geography 19(1): 33-38.

http://dx.doi.org/10.1016/j.jtrangeo.2009.11.006

Best, H.; Lanzendorf, M. 2005. Division of labour and gender differences in metropolitan car use: an empirical study in Cologne, Germany, Journal of Transport Geography 13(2): 109-121. http://dx.doi.org/10.1016/j.jtrangeo.2004.04.007

Boarnet, M. G.; Sarmiento, S. 1998. Can land-use policy really affect travel behaviour? A study of the link between non-work travel and land-use characteristics, Urban Studies 35(7): 1155-1169.

http://dx.doi.org/10.1080/0042098984538

Bohte, W.; Maat, K. 2009. Deriving and validating trip purposes and travel modes for multi-day GPS-based travel surveys: A large-scale application in the Netherlands, Transportation Research Part C: Emerging Technologies 17(3): 285-297. http://dx.doi.org/10.1016/j.trc.2008.11.004

Bonham, J.; Koth, B. 2010. Universities and the cycling culture, Transportation Research Part D: Transport and Environment 15(2): 94-102. http://dx.doi.org/10.1016/j.trd.2009.09.006

Bowersox, D. J. 1974. Logistical Management. Collier Macmillan Ltd. 512 p.

Bowersox, D. J.; Closs, D. J.; Stank, T. P. 2000. Ten mega-trends that will revolutionize supply chain logistics, Journal of Business Logistics 21(2): 1-16.

Christiaanse, E.; Zimmerman, R.-J. 1999. Managing electronic channels: the KLM cargo cyberpets case, Journal of Information Technology 14(2): 123-135. http://dx.doi.org/10.1080/026839699344629

Christopher, M. 2005. Logistics and Supply Chain Management: Creating Value-Adding Networks. 3rd edition. FT Press. 320 p.

Cools, M.; Creemers, L. 2013. The dual role of weather forecasts on changes in activity-travel behavior, Journal of Transport Geography 28: 167-175.

http://dx.doi.org/10.1016/j.jtrangeo.2012.11.002

Evenson, K. R.; Huston, S. L.; McMillen, B. J.; Bors, P.; Ward, D. S. 2003. Statewide prevalence and correlates of walking and biking to school, Archives of Pediatrics \& Adolescent Medicine 157(9): 887-892. http://dx.doi.org/10.1001/archpedi.157.9.887

Fiorenzo-Catalano, S.; Hoogendoorn-Lanser, S.; Van Nes, R. 2003. Choice set composition modelling in multi-modal travelling, in Moving through Nets: The Physical and Social Dimensions of Travel: 10th International Conference on Travel Behaviour Research, 10-15 August 2003, Lucerne, Switzerland, 1-24. 
Gardner, B.; Abraham, C. 2008. Psychological correlates of car use: a meta-analysis, Transportation Research Part F: Traffic Psychology and Behaviour 11(4): 300-311.

http://dx.doi.org/10.1016/j.trf.2008.01.004

Garver, M. S.; Williams, Z.; Taylor, G. S.; Wynne, W. R. 2012. Modelling choice in logistics: a managerial guide and application, International Journal of Physical Distribution \& Logistics Management 42(2): 128-151. http://dx.doi.org/10.1108/09600031211219654

Gatersleben, B.; Haddad, H. 2010. Who is the typical bicyclist? Transportation Research Part F: Traffic Psychology and Behaviour 13(1): 41-48. http://dx.doi.org/10.1016/j.trf.2009.10.003

Gehrt, K. C.; O’Brien, M. 2003. Consumer logistics: scale development in a services market and exploration of influence on value and satisfaction, The Annual Bulletin: Japan Academy of Personal Finance (3): 93-95.

Gehrt, K. C.; Rajan, M. 2007. A Consumer Logistics Framework for Understanding Preferences for High-Speed Rail Transportation. MTI Report 05-04. Mineta Transportation Institute. 46 p. Available from Internet: http://transweb.sjsu.edu/MTIportal/research/publications/summary/0504.html

Gehrt, K. C.; Rajan, M.; O’Brien, M.; Sakano, T.; Onzo, N. 2007. Understanding preference for high-speed rail service: a consumer logistics perspective, Innovative Marketing 3(4): 32-41.

Granzin, K. L. 1990. The consumer logistics system: a focal point for study of the household-consumption process, Journal of Consumer Studies \& Home Economics 14(3): 239-256.

http://dx.doi.org/10.1111/j.1470-6431.1990.tb00052.x

Granzin, K. L.; Bahn, K. D. 1989. Consumer logistics: conceptualization, pertinent issues and a proposed program for research, Journal of the Academy of Marketing Science 17(1): 91-101. http://dx.doi.org/10.1007/BF02726358

Gupta, S.; Loulou, R. 1998. Process innovation, product differentiation, and channel structure: strategic incentives in a duopoly, Marketing Science 17(4): 301-316. http://dx.doi.org/10.1287/mksc.17.4.301

Hagman, O. 2010. Driving pleasure: a key concept in Swedish car culture, Mobilities 5(1): 25-39.

http://dx.doi.org/10.1080/17450100903435037

Handy, S. L.; Xing, Y.; Buehler, T. J. 2010. Factors associated with bicycle ownership and use: a study of six small U.S. cities, Transportation 37(6): 967-985.

http://dx.doi.org/10.1007/s11116-010-9269-x

Higuchi, D.; Sakano, T. 2003. Understanding consumer financial services transactions in Japan: a consumer logistics framework, Waseda Business \& Economic Studies 39: 1-19.

Hume, C.; Timperio, A.; Salmon, J.; Carver, A.; Giles-Corti, B.; Crawford, D. 2009. Walking and cycling to school: predictors of increases among children and adolescents, American Journal of Preventive Medicine 36(3): 195-200. http://dx.doi.org/10.1016/j.amepre.2008.10.011

Irawan, M. Z.; Sumi, T. 2011. Promoting active transport in students' travel behavior: a case from Yogyakarta (Indonesia), Journal of Sustainable Development 4(1): 45-52. http://dx.doi.org/10.5539/jsd.v4n1p45

Jacobucci, C. 2002. Impact of Discounted University Student Transit Fares on Winnipeg's Public Transit System. Student Paper 16. Institute of Urban Studies, The University of Winnipeg. 24 p. Available from Internet: http://www.uwinnipeg.ca/faculty/ius/iusweb/pdf/Jacobucci.pdf
Johansson, M. V.; Heldt, T.; Johansson, P. 2006. The effects of attitudes and personality traits on mode choice, Transportation Research Part A: Policy and Practice 40(6): 507-525. http://dx.doi.org/10.1016/j.tra.2005.09.001

Kamruzzaman, M.; Hine, J.; Gunay, B.; Blair, N. 2011. Using GIS to visualise and evaluate student travel behaviour, Journal of Transport Geography 19(1): 13-32.

http://dx.doi.org/10.1016/j.jtrangeo.2009.09.004

Kerr, A.; Lennon, A.; Watson, B. 2010. The call of the road: factors predicting students' car travelling intentions and behaviour, Transportation 37(1): 1-13.

http://dx.doi.org/10.1007/s11116-009-9217-9

Khattak, A.; Wang, X.; Son, S.; Agnello, P. 2011. Travel by university students in Virginia: is this travel different from travel by the general population?, Transportation Research Record 2255(2): 137-145. http://dx.doi.org/10.3141/2255-15

Kotler, P.; Keller, K. L. 2011. Marketing Management. 14th edition. Prentice Hall. 816 p.

Lois, D.; López-Sáez, M. 2009. The relationship between instrumental, symbolic and affective factors as predictors of car use: a structural equation modeling approach, Transportation Research Part A: Policy and Practice 43(9-10): 790-799. http://dx.doi.org/10.1016/j.tra.2009.07.008

Manaugh, K. 2009. Neighbourhood Level Determinants on Mode Choice and Distance for Home-Based Work Trips in the Montréal Region: a Factor and Cluster Analysis of Demographic, Urban form and Accessibility Measures to Better Understand Regional Travel Behaviour. Supervised Research Paper. In partial fulfillment of the Masters of Urban Planning Degree School of Urban Planning. McGill University, Montreal. 63 p. Available from Internet: http://tram.mcgill. $\mathrm{ca} /$ Teaching/srp/documents/Kevin.pdf

McMillan, T. E. 2007. The relative influence of urban form on a child's travel mode to school, Transportation Research Part A: Policy and Practice 41(1): 69-79. http://dx.doi.org/10.1016/j.tra.2006.05.011

Murtagh, N.; Gatersleben, B.; Uzzell, D. 2012. Self-identity threat and resistance to change: evidence from regular travel behaviour, Journal of Environmental Psychology 32(4): 318-326. http://dx.doi.org/10.1016/j.jenvp.2012.05.008

Painter, J. J.; Granzin, K. L. 1996. Segmenting the retail market using shoppers' participation in consumer logistics, selfperception, and demographics, in Proceedings of the 1996 Academy of Marketing Science (AMS) Annual Conference, 29 May - 1 June 1996, Phoenix, Arizona, 199-200. http:// dx.doi.org/10.1007/978-3-319-13144-3_60

Rajé, F. 2007. Using Q methodology to develop more perceptive insights on transport and social inclusion, Transport Policy 14(6): 467-477.

http://dx.doi.org/10.1016/j.tranpol.2007.04.006

Reutterer, T.; Kotzab, H. W. 2000. The use of conjoint-analysis for measuring preferences in supply chain design, Industrial Marketing Management 29(1): 27-35. http://dx.doi.org/10.1016/S0019-8501(99)00109-1

Rouquet, A.; Goudarzi, K.; Henriquez, T. 2011. The transfer of logistics services between a company and its consumers, in Proceedings of the 23rd Annual NOFOMA Conference: Logistics and Supply Chain Management in a High North Perspective, 9-10 June 2011, Harstad, Norway.

Savaskan, R. C.; Van Wassenhove, L. N. 2006. Reverse channel design: the case of competing retailers, Management Science 52(1): 1-14. http://dx.doi.org/10.1287/mnsc.1050.0454 
Shuttleworth, I.; Gould, M. 2010. Distance between home and work: a multilevel analysis of individual workers, neighbourhoods, and employment sites in Northern Ireland, Environment and Planning A 42(5): 1221-1238.

http://dx.doi.org/10.1068/a41372

Silver, S. 2011. User Evaluations of Intermodal Travel to Work: Exploratory Studies. MTI Report WP 10-03. Mineta Transportation Institute, San José. 56 p. Available from Internet: http://transweb.sjsu.edu/project/1025.html

Teller, C.; Reutterer, T.; Schnedlitz, P. 2008. Hedonic and utilitarian shopper types in evolved and created retail agglomerations, The International Review of Retail, Distribution and Consumer Research 18(3): 283-309.

http://dx.doi.org/10.1080/09593960802113877

Van Exel, N. J. A.; Rietveld, P. 2009. Could you also have made this trip by another mode? An investigation of perceived travel possibilities of car and train travellers on the main travel corridors to the city of Amsterdam, The Netherlands, Transportation Research Part A: Policy and Practice 43(4): 374-385. http://dx.doi.org/10.1016/j.tra.2008.11.004

Vovsha, P.; Petersen, E. 2005. Escorting children to school: statistical analysis and applied modeling approach, Transportation Research Record 1921: 131-140.

http://dx.doi.org/10.3141/1921-15

Xu, F.; Morgan, M.; Song, P. 2009. Students' travel behaviour: a cross-cultural comparison of UK and China, International Journal of Tourism Research 11(3): 255-268.

http://dx.doi.org/10.1002/jtr.686

Waite, K.; Harrison, T. 2002. Consumer expectations of online information provided by bank websites, Journal of Financial Services Marketing 6(4): 309-322.

http://dx.doi.org/10.1057/palgrave.fsm.4770061

Wang, X.; Khattak, A. J.; Son, S. 2012. What can be learned from analyzing university student travel demand?, Transportation Research Record 2322: 129-137.

http://dx.doi.org/10.3141/2322-14 